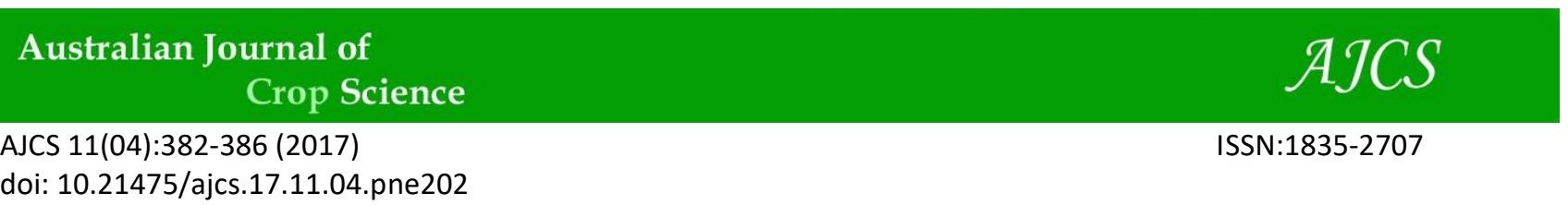

\title{
Titanium (Ti) in plant nutrition - A review
}

\section{Fernando Simoni Bacilieri*, Ana Carolina Pereira de Vasconcelos, Regina Maria Quintão Lana, José Geraldo Mageste, José Luiz Rodrigues Torres}

\author{
Institute of Agricultural Sciences, Federal University of Uberlândia (UFU) 38400-000, Uberlândia, MG, Brazil \\ *Corresponding author: ferbacilieri@zipmail.com.br
}

\begin{abstract}
Several studies have been carried out on the application of titanium in plant nutrition in recent decades. They indicate that this element has a positive effect on crop phenological events such as germination, root formation, vegetative growth, maturation, as well as resistance to biotic or abiotic stress conditions and general crop health status. Titanium has also been reported to boost the uptake of macro and micronutrients, enzymatic activity in plants, and consequently increase yield. Therefore, pioneering studies of foliar applications of titanium in potato crops are being carried out in Brazil. They demonstrate that titanium reduces urease enzyme activity, but increases peroxidase and nitrate reductase activity during potato growth. During tuberization, there is a positive correlation between superoxide dismutase \& peroxidase enzyme activity and titanium application. Although the results are promising, more data is needed regarding the effects of this element on crop performance. This review describes the characteristics of this element and reports innovations regarding its use in plant nutrition.
\end{abstract}

Received 14 June 2016; Revised 4 January 2017; Accepted 13 January 2017.

Keywords: plant nutrition, nutrient absorption, beneficial element, foliar fertilization.

Abbreviations: Ti_titanium, N_nitrogen, Ni_nickel, PL_lipid peroxidation, ANR_activity of nitrate reductase, SOD_superoxide dismutase, POD_peroxidase, CAT_catalase, ROS_reactive oxygen species.

\section{Introduction}

Titanium dioxide $\left(\mathrm{TiO}_{2}\right)$ is naturally found in three structural forms: two in tetragonal form (anatase and rutile), and one in orthorhombic form (broquite), which is less common in nature. The bulk of $\mathrm{TiO}_{2}$ is extracted from the mineral ilmenite $\left(\mathrm{FeTiO}_{3}\right)$, which is found in metamorphic and igneous rocks (Skocaj et al., 2011), and which considering the optimum $\mathrm{pH}$ range for most crops of 4.0-8.0 is insoluble, thus unavailable to plants and also without possible toxic effects (Dumon and Ernst, 1988).

Titanium (Ti) stands out among the transition elements because of the possibility of valence change. For that reason, it participates in electron transfer processes connected to photosynthesis. In recent years, due to the emergence of a Tiascorbate compound, which can be used in plants via foliar, some reports started to communicate the use of Ti in different crops with significant results in biomass production, yield, accelerated ripening, fruit quality, increased photosynthesis, increased protein and chlorophyll synthesis, as well as improvements in enzymatic activity of peroxidase, catalase, nitrogenase and nitrate reductase (Alcaraz et al., 1991).

Several authors report that $\mathrm{Ti}$ can increase the yield from about 5 to $50 \%$ in various crops (Pais, 1983; Balík et al., 1989; Carvajal and Alcaraz, 1998). Also, the application of $\mathrm{Ti}$ in crop production has been reported to reduce the severity of disease, promote plant growth, and increase photosynthetic rate (Chao and Choi, 2005).

Titanium can be considered a beneficial nutrient (Carvajal and Alcaraz, 1998; Pais et al., 1977). Some studies of Ti application in a wide range of plant species indicate improvements for the following traits: germination, yield of biomass, protein synthesis, uptake of nutrients, activity of antioxidant enzymes, photosynthesis, and fruit quality (Carvajal and Alcaraz, 1998).

Kuzel et al. (2003) consider the so-called "hormesis" effect as one of the beneficial effects of $\mathrm{Ti}$ in agriculture. This theory states that a potentially harmful substance, when applied at low doses, has a beneficial effect on the plant, for example it can increase the enzymatic activity or facilitate the uptake of an essential nutrient. In this case, the application of a stressor within the hormetic zone produces favorable plant response.

For Ti, which is still not considered an essential nutrient in the production of plants, foliar fertilization can be beneficial because Ti supply via soil is not effective as this element is characterized by low mobility in soil and presents limited uptake by roots. Regarding its adverse effects, neither damage to the plants when Ti was used at higher doses than the recommended (Frazer, 2001), nor harmful effects after the consumption of agricultural products sprayed with $\mathrm{Ti}$ have been reported to date (NPL, 2002).

Titanium and the concentration of macro and micronutrients

The use of $\mathrm{Ti}$ appears to increase concentrations of some essential elements, both macro and micronutrients. Experiments have demonstrated that $\mathrm{Ti}$ chelates are able to promote the development of young plants and can increase the activity of some enzymes (Botia et al., 2002). Further, Ti has been found in the mineral composition of all groups of 
plants (El-Ghonemy et al., 1977; Guha and Mitchell, 1965), fungi (Silverman and Muñoz, 1971) and lichen (Takala and Olkkonen, 1985) with the largest concentrations in aquatic organisms (Dumon and Ernst, 1988).

Studies show positive effects of Ti applications on the absorption of essential elements; although, Bedrosian and Hanna (1966) report deficiencies of iron (Fe) and manganese (Mn) in Pieris japonica due to increased absorption of Ti. Still, Giménez et al. (1990), working with pepper (Capsicum annuum), report that the concentrations of some macro and micronutrients were higher when plants received foliar applications of Ti. Haghighi et al. (2012) demonstrated that 1 $\mathrm{mg} \mathrm{Ti} \mathrm{L} \mathrm{L}^{-1}$ can compensate for the absorption of nitrogen $(\mathrm{N})$ when the dose is reduced by $50 \%$. This procedure did not alter the fresh and dry matter of shoots and roots, flowering time, number of flowers, chlorophyll content and photosynthetic capacity of tomato plants. In other experiments, up to $50 \%$ of total $\mathrm{N}$ was removed from the fertilizer applied in crops treated with $\mathrm{Ti}$, which also did not produce any nutritional imbalance in plants (Frutos et al., 1996). Similar results were obtained with reduced applications of phosphorus (P) (Lopez-Moreno et al., 1996). There are also reports that the concentration of $\mathrm{Fe}$ in pepper plants treated with Ti was higher than in the control, and that the increase was higher relative to the other nutrients (Carvajal et al., 1995).

Interestingly, this increase in nutrient absorption decreases when plants are under optimal nutritional conditions. In some comparative studies on various varieties of Capsicum annuum grown under different conditions, it was observed that the effects of $\mathrm{Ti}$ varied, from maximum absorption with traditional fertilization to minimum under ideal conditions of controlled environment of hydroponic crop (Giménez et al., 1990; Martínez-Sánchez et al., 1991).

Konishi and Tsuge (1936) suggested that $\mathrm{Ti}$ in the form of Ti oxide may play a part in symbiotic nitrogen fixation $(\mathrm{N})$ in legume nodules. They also stated that potassium titanate added to the crop of alfalfa can enhance growth. A large amount of $\mathrm{Ti}$ has been found in plants, particularly in the leaves and stems. Inman et al. (1935) also reported that $\mathrm{Ti}$ enhances root growth and speculated that it may occur due to reduced toxicity of some other elements.

Therefore, Ti can be considered a beneficial element in plants in view of the effects it produces. However, as this element is not available to plants under natural conditions, it is necessary to study its foliar application as a soluble compound.

\section{Titanium and the activity of enzymes}

The activity of catalase, peroxidase and nitrate reductase can increase after the addition of $\mathrm{Ti}$ in wheat and corn (Pais, 1983) and bell pepper (Carvajal et al., 1994). Lu et al. (2002) demonstrated that a combination of nanoparticles of $\mathrm{SiO}_{2}$ and $\mathrm{TiO}_{2}$ may enhance the activity of enzymes and antioxidants in soybean (Glycine max), promote the uptake of water and nutrients, and accelerate germination and growth. Furthermore, $\mathrm{TiO}_{2}$ can improve resistance of plants to stress conditions (Navarro et al., 2008).

Recently, new data were obtained by Bacilieri (2015) who studied the effect of titanium doses on proline content, lipid peroxidation (PL), and the activity of enzymes nitrate reductase (ANR), urease, superoxide dismutase (SOD), peroxidase (POD) and catalase (CAT) during growth, tuberization and tuber-filling phases of potatoes in Brazil.

During the growth and tuberization, the activity of enzymes ANR, urease, SOD, POD and CAT was positively correlated with the application of Ti. Also, enzymes ANR, urease, proline and CAT showed a significant activity during the tuber-filling stage in treatments with Ti. The best fit for the data was a cubic model.

During the growth phase, ANR activity increased with Ti doses. In this case, the best fit for the dataset was a linear model with a positive relationship at the studied doses. Importantly, this stage is characterized by plant maximum growth with high demand for nitrogen compounds. The assimilation of $\mathrm{N}$ via nitrate is crucial and the activity of nitrate reductase signals vegetative growth and adequate $\mathrm{N}$ supply. During tuberization, the best fit for ANR data was a negative linear model with a determination coefficient of $52.14 \%$. Reduction of ANR activity may occur because N metabolism is reduced and the formation of the plant structure is already set. At tuber-filling stage, ANR activity was higher in treatments with $\mathrm{Ti}$ relative to the control treatment, even when $\mathrm{N}$ doses decreased in relation to Ti doses.

Urease activity was also influenced by Ti doses. During the growth phase, the control treatment showed the highest activity, and the best fit for this trait was a quadratic model. The fit equation shows that during this stage the lowest dose of $\mathrm{Ti}$, which was $3.4 \mathrm{~g} \mathrm{ha}^{-1}$, reduced urease activity. The activity of this enzyme depends on nickel (Ni). The role of $\mathrm{Ni}$ in the metabolism of metals such as $\mathrm{Fe}$, inducing deficiency of this nutrient, was observed in work conducted by Chaney (1970) and Agarwala et al. (1977). The application of Ti appears to inhibit the absorption of $\mathrm{Ni}$ and reduce the activity of urease at this stage. During tuberization, up to a dose of $3.98 \mathrm{~g}$ of $\mathrm{Ti}$, urease activity was reduced. The primary function of urease is to catalyze the transformation of internally or externally generated urea into a source of $\mathrm{N}$. Up to $47 \%$ of $\mathrm{N}$ flow in plants occurs through urea, which is recycled by urease (Pollacco and Holland, 1993). With the reduction of ANR, urease activity increases to encourage the use of internal N. During tuber-filling, urease showed a $98.25 \%$ fit to a cubic model. Again, in general, the values were lower than in the control without $\mathrm{Ti}$ application, suggesting that $\mathrm{Ti}$ can inhibit the absorption of $\mathrm{Ni}$, which is a constituent of this enzyme. There is no available data regarding the absorption of $\mathrm{Ni}$, or its relationship with other elements such as Ti. However, this nutrient is believed to require high regulation of mobilization and translocation of $\mathrm{Ni}$ in older leaves to reproductive organs (Römheld, 2007).

The best fit for proline behavior was a cubic model. The application of $2.68 \mathrm{~g} \mathrm{Ti} \mathrm{ha}^{-1}$ resulted in maximum proline content during the growth phase. This amino acid is a biochemical marker of metabolic changes generated by different types of stress conditions. (Lima, 2004) It is synthesized by glutamate, and also by the arginine/ornithine cycle which has the same route as urease. At this phase, it was found that proline synthesis may be favored by low activity of urease. The best fit for proline behavior during tuberization was a cubic model, where lack of Ti application resulted in higher proline content $\left(1.26 \mu \mathrm{mol} \mathrm{g}{ }^{-1} \mathrm{MF}\right)$. An excessive synthesis of this amino acid can be harmful to plants since it consumes $0.4-0.6 \%$ of total foliar N (Ernst et al., 2000), and thus high proline synthesis may consume part of $\mathrm{N}$ which could otherwise be used for tuber filling.

Considering proline levels during tuberization, its levels were generally lower in treatments with $\mathrm{Ti}$ than in the control. The metabolic pathway responsible for the most significant proline synthesis in plants begins with amino acid glutamate, which can be produced by hydrolyzing proteins in transamination reactions, or in reactions catalyzed by GS/GOGAT cycle (Valpuesta et al., 1992). As accumulated 
proline may originate from glutamate synthesized with assimilated $\mathrm{N}$, the reduction of $\mathrm{N}$ content as a result of $\mathrm{Ti}$ applications may cause the reduction of proline content.

The activity of SOD, POD and CAT were affected by treatments during the growth phase. The best fit for SOD and CAT was a cubic model, and for POD a positive linear model. The balance between the activities of SOD, CAT or POD in cells is crucial to determine the level of superoxide radicals and $\mathrm{H}_{2} \mathrm{O}_{2}$ (Mittler, 2002). As $\mathrm{Mn}$ content was reduced with the applications of $\mathrm{Ti}$, it may have changed the activity of SOD. POD is involved in stress tolerance mechanisms, including plant exposure to heavy metals (Passardi et al., 2005). The highest dose of Ti $\left(8.5 \mathrm{~g} \mathrm{ha}^{-1}\right)$ increased POD activity by up to $21 \%$. Thus, it is important to test the effects of higher doses than the applied in this study, especially under stress conditions. The variation in CAT activity can be justified in almost $50 \%$ by the doses of Ti. Here, the best fit for the data was a cubic model. The minimum CAT activity was observed at $1.8 \mathrm{~g} \mathrm{Ti} \mathrm{ha}^{-1}$ and maximum at $6.1 \mathrm{~g} \mathrm{Ti} \mathrm{ha}^{-1}$ within the studied range.

During tuberization, the best fit for POD enzyme activity as a function of Ti doses was a cubic model. This enzyme is widely distributed in higher plants and it participates in various processes including lignification, metabolism of auxins, and response mechanisms to stress conditions caused by salt and heavy metals. Increased POD activity can occur as a metabolic response related to different types of stress conditions (Anderson et al., 1995; Zhang and Kirkham, 1996; Jiménez et al., 1998; Moraes et al., 2002).

Regarding the behavior of SOD as a response to Ti doses, the treatments with $\mathrm{Ti}$ showed higher activity than the control. This enzyme depends on metal nutrients which act as cofactors, where $\mathrm{Zn}, \mathrm{Mn}, \mathrm{Fe}$ and $\mathrm{Cu}$ play an important role. The application of $\mathrm{Ti}$ favored Fe absorption. Also, high $\mathrm{Cu}$ levels observed during this phase of crop development may be caused by an increased SOD activity.

The activity of CAT was minimal at $4.08 \mathrm{~g} \mathrm{Ti} \mathrm{ha}^{-1}$ and maximum with the application of $14.86 \mathrm{~g} \mathrm{Ti} \mathrm{h}^{-1}$. An increase of CAT activity was observed from the dose of $4.08 \mathrm{~g} \mathrm{Ti} \mathrm{ha}^{-1}$. This demonstrates that Ti helps activate CAT, which is active in detoxification of hydrogen peroxide, maintaining the oxidative balance in plant cells. The increase in the activity of this enzyme is a form of plant defense because it protects cell structures (Gunes et al, 2007).

During the tuber-filling stage, POD activity was the highest, although it was not influenced by $\mathrm{Ti}$ doses. The minimum dose for CAT activity was $6.41 \mathrm{~g} \mathrm{~h}^{-1}$. Such changes in CAT activity may occur as a response to extreme environmental conditions (Kalir and Poljakoff-Mayber, 1981; Broetto et al., 2002).

The behavior of PL reflects a chain of biochemical events caused by the action of free radicals on cell membranes, leading to the destruction of its structure, failure of metabolite exchange mechanisms and, in an extreme case, to the death of the cell (Benzie, 1996). The alterations in membranes lead to permeability disorders, alter ionic flow, and the flow of other substances, thus causing the loss of selectivity for entry and/or exit of nutrients and toxic substances to the cell, as well as changes in gene expression, oxidation and involvement of extracellular matrix components (Vaca et al., 1988; Barber and Harris, 1994). In general, PL presented activity below the control treatment during the growth stage. It is desirable because it confirms that the activity of SOD, CAT and POD was a function of Ti, and not a response to biotic or abiotic stress conditions.

The quantification of PL serves as an indication of cellular damage rate caused by free radicals. During tuberization, PL activity was below the control treatment, and the best fit for the data was a cubic model. High production of reactive oxygen species (ROS) is appointed as a mechanism of toxicity of various metals. Thus, it can be inferred that there was no toxicity caused by Ti doses. During the tuber-filling stage, PL was not significantly affected by Ti doses. This fact leads to a conclusion that $\mathrm{Ti}$ application up to a dose $25.5 \mathrm{~g}$ $\mathrm{Ti} \mathrm{ha}^{-1}$, which was a maximum dose tested in this experiment, in not toxic for the potato crop. High levels of oxidizing radicals in the presence of toxic levels of metals associated with peroxidation of membrane lipids (Devi and Prasad, 2004; Romero-Puertas et al., 2006) cause oxidative damage to membranes, changes in permeability of cell membrane (Kabata-Pendias, 2000), and changes in fluidity, activity, and structural conformation of membrane-bound enzymes.

The results in Brazil show that a foliar application of $\mathrm{Ti}$ during potato growth reduces the activity of urease, but increases the activity of peroxidase, and nitrate reductase. During tuberization there is a positive response in the activity of superoxide dismutase and peroxidase to increasing doses of Ti.

There are reports in literature that wheat (Keleme et al., 1993), oat (Kuzel et al., 2003), bell pepper (MartínezSánchez et al., 1991), Pieris japonica (Bedrosian and Hanna, 1966), tomato (Haghighi et al., 2012), corn (Pais, 1983), chili peppers (Giménez et al., 1990) and soybeans (Navarro et al., 2008) respond to the application of $\mathrm{Ti}$ with increased productivity, nutrient uptake, biomass production, accelerated maturation and fruit quality. Hence, it is clear that further research of this nutrient for its use in agriculture is important.

\section{Conclusion}

Titanium improves nutritional status of plants, stimulates enzymatic activity, accelerates the uptake of nutrients, increases photosynthesis, participates in the synthesis of proteins \& chlorophyll, and in the control of plant diseases.

This nutrient presents positive and negative interactions with other essential elements; however, such interactions are yet to be fully understood. Titanium doses, forms, application methods, application periods; fertilizers containing $\mathrm{Ti}$ in plant-available forms, and crops which are responsive to its presence also need further studies.

\section{Acknowledgements}

The authors gratefully acknowledge the financial support of Coordination of Improvement of Higher Education Personnel (CAPES), National Council for Scientific and Technological Development $(\mathrm{CNPq})$ and the Foundation for Research Support of the State of Minas Gerais - FAPEMIG.

\section{References}

Agarwala SC, Bisht SS, Sharma CP (1977) Relative effectiveness of certain heavy metals in producing toxicity and symptoms of iron deficiency in barley. Can J Bot. 55 (10): 1299-1307.

Alcaraz CF, Sánchez MF, Giménez JL (1991) Ascorbato de titanio, fertilizante foliar. Agri. 708: 636-638.

Anderson MD, Prasad TK, Stewart CR (1995) Changes in isozyme profiles of catalase, peroxidase, and glutathione reductase during acclimation to chilling in mesocotylus of maize seedlings. Plant Physiol. 109: 1247-1257.

Bacilieri FS (2015) Titânio via foliar no metabolismo, absorção de nutrientes e produtividade de batata. Universidade Federal de Uberlândia, Uberlândia. 76. 
Balík J, Vostal J, Tlustoš P (1989) Results of Titavin tests for chosen crops. In: Sborník VŠZ, Praha. Řada A. 50: 143155 .

Barber DA, Harris SR (1994) Oxygen free radicals and antioxidants: A review. Am Pharm. 34: 26-35.

Bedrosian AJ, Hanna WJ (1966) Trace element relationships in New Jersey soils. Soil Sci. 101 (1): 50-56.

Benzie IFF (1996) Lipid peroxidation: a review of causes, consequences, measurements and dietary influences. Int J Food Sci Nutr. 47: 233-61.

Botia M, Alcaraz-Lòpez C, Alcaraz FR (2002) Effect of the foliar application of sprays containing calcium, amino acid and titanium on Capsicum (Capsicum annuиm L., cv Olmo) fruit quality. In: Simposio Ibérico Sobre Nutrición Mineral De Las Plantas, IX. 2002, Zaragoza. Comunicaciones... Zaragoza: CSIC, 203-206.

Broetto F, Luttge U, Ratajczak R (2002) Influence of light intensity and salt treatment on mode of photosynthesis and enzymes of the antioxidative response system of mesembryanthemum crystallinum. Funct Plant Biol. 29: 13-23.

Carvajal M, Martínez-Sánchez F, Pastor JJ, Alcaraz CF (1995) Leaf spray with Ti (IV) ascorbate improves the iron uptake and iron activity in Capsicum annuum L. plants, pp. 1-5. In: J. Abadía (ed.), Iron Nutrition in Soils and Plants. Kluwer Academic Publishers, Dordrecht, The Netherlands.

Carvajal M, Alcaraz CF (1998) Why titanium is a beneficial element for plants. J Plant Nutr. 21 (4): 655-664.

Carvajal M, Martínez-Sánchez F, Alcaraz CF (1994) Effect of Ti (IV) application on some enzymatic activities in several developing stages of Capsicum annuиm L. plants. J Plant Nutr.17: 243-253.

Chaney RL (1970) Effect of nickel ou iron meial,olism by soybeans Lafayette, Ind, Purdue University, 192p. Ph.D. Thesis. Dias. Absin Ini. 31: 1692-3.

Chao SH, Choi HS (2005) Method for providing enhanced photosynthesis. Korea Research Institute of Chemical Technology, Jeonju, South Korea. Bulletin 10 pp.

Devi SR, Prasad MNV (2004) Membrane lipid alterations in heavy metal exposed plants. In: Prasad MNV (Ed) Heavy metal stress in plants: from biomolecules to ecosystems, 2nd ed. New Delhi: Springer. 127-145.

Dumon JC, Ernst WHO (1988) Titanium in plants. J Plant Physiol. 133 (2): 203-209.

El-Ghonemy AA, El-Gazzar AM, Wallace A, Romney EM (1977) Mineral element composition of the natural vegetation along a transect at Mareotis. Egypt Soil Sci. 124:16-26.

Ernst WHO, Nelissen HJM, TenBookum WM (2000) Combination toxicology of metal-enriched soils: physiological responses of $\mathrm{Zn}$ and $\mathrm{Cd}$ resistant ecotype of Silene vulgaris on polymetallic soil. Environ Exp Bot. 43: $55-71$.

Frazer L (2001) Titanium dioxide: Environmental white knight. Environ Health Perspect. 109: 174-177.

Frutos MJ, Pastor JJ, Martínez-Sánchez F, Alcaraz CF (1996) Improvement of the nitrogen uptake induced by titanium leaf supply in nitrogen-stressed pepper seedlings. J Plant Nutr. 19: 771-783.

Giménez JL, Martínez-Sánchez F, Moreno A, Fuentres JL, Alcaraz CF (1990) Titanium in plant nutrition. III. Effect of Ti (IV) on yield of Capsicum anuum L. In: Proceedings of III. Symposium Nacional de Nutrición Mineral de las Plantas, Nutrición Mineral bajo condiciónes de Estrés. $123-128$.
Guha MM, Mitchell RL (1965) The trace and major element composition of the leaves of some deciduous trees. I. Sampling techniques. Plant Soil. 23: 323-338.

Gunes A, Inal A, Baggi EG, Coban S, Pilbean DJ (2007) Silicon mediates changes to some physiological and enzymatic parameters symptomatic for oxidative stress in spinach (Spinacia oleracea L.) grown under B toxicity. Sci Hort. 113: 113-119.

Haghighi M, Heidarian S, da Silva JAT (2012) The effect of titanium amendment in $\mathrm{N}$-withholding nutrient solution on physiological and photosynthesis attributes and micronutrient uptake of tomato. Biol Trace Elem Res. 150 (1-3): 381-390.

Inman OL, Barclay G, Hubbard M (1935) Effect of titanium chloride on the formation of chlorophyll in Zea mays. Plant Physiol. 10: 821-822.

Jiménez A, Hernández JA, Pastori G, Del Rio LA, Sevilla F (1998) Role of ascorbate-glutathione cycle of mitochondria and peroxisomes in the senescence of pea leaves. Plant Physiol. 118: 1327-1335.

Kabata-Pendias A (2000) Trace Elements in Soils \& Plants. CRC Press, Boca Raton, USA.

Kalir A, Poljakoff-Mayber A (1981) Changes in activity of malate dehydrogenase, catalase, peroxidase and superoxide dismutase in leaves of Halimione portulacoides (L.) Aellen exposed to high sodium chloride concentrations. Ann Bot. 47 (1): 75-85.

Keleme G, Keresztes A, Bacsy E, Feher M, Fodor P, Pais I (1993) Distribution and intracellular-localization of titanium in plants after titanium treatment. Food Struct. 12: 67-72.

Konishi K, Tsuge T (1936) Inorganic constituents of greenmanure crops. II J Agric Chem Soc. 12: 916-930.

Kuzel S, Hruby M, Cigler P, Tlustos P, Van PN (2003) Mechanism of Physiological Effects of Titanium Leaf Sprays on Plants Grown on Soil. Biol Trace Elem Res. 91 (2): 179-190.

Lima MGS (2004) Efeito do estresse salino sobre a concentração de pigmentos e prolina em folhas de arroz. Bragantia. 63 (3): 335-340.

Lopez-Moreno JL, Gimenez JL, Moreno A, Fuentes JL, Alcaraz CF (1996) Plant biomass and fruit yield induction by Ti (IV) in P-stressed pepper crops. Fert Res. 43: 131136.

Lu CM., Zhang CY, Wu JQ, Tao MX (2002) Research of the effect of nanometer on germination and growth enhancement of Glycine max and its mechanism. Soybean Sci. 21: 168-172.

Martínez-Sánchez F, Carvajal M, Frutos MJ, Giménez JL, Alcaraz CF (1991) Titanium in the nutrition of Capsicum annuum L. plants. Ci Agro. 11:73-78.

Mittler R (2002) Oxidative stress, antioxidants and stress tolerance. Trends Plant Sci. 7: 405-410.

Moraes RM, Klump A, Furlan CM, Klump G, Domingos M, Rinaldi MCS, Modesto IF (2002) Tropical fruit trees as bioindicator of industrial air pollution in Southeast Brazil. Environ Int. 28: 367-374.

NANO-PLANT TECHNOLOGY (NPL) (2002) Method of accelerating metabolism and growth of plant using the corpuscular of Titanium Dioxide. A handbook. Sun Plus Corp., Korea.

Navarro E, Baun A, Behra R, Hartmann NB, Filser J, Miao A, Quigg A, Santschi PH, Sigg L (2008) Environmental behavior and ecotoxicity of engineered nanoparticles to algae, plants, and fungi. Ecotoxicology. 17: 372-386.

Pais I (1983) The biological importance of titanium. J Plant Nutr. 6: 3-131. 
Pais I, Fehér M, Farkas E, Szabó Z, Cornides I (1977) Titanium as a new trace element. Commun Soil Sci Plant Anal. 8 (5): 407-410.

Passardi F, Cossio C, Penel C, Dunand C (2005) Peroxidases have more functions than a Swiss army knife. Plant Cell Rep. 24: 255-265.

Pollacco JC, Holland MA (1993) Roles of urease in plant cells; in International Review of Cytology (Jeon, K.W. \& Jarvik, J., eds.) 145, 65-103, Academic Press, Inc., San Diego.

Romero-Puertas MC, Corpas FJ, Sandalio LM, Leterrier M, Rodríguez-Serrano M, Del Río LA, Palma JM (2006) Glutathione reducatse from pea leaves: response to abiotic stress and characterization of the peroxisomal isozyme. New Phytol. 170: 43-52.

Römheld V (2007) Dinâmica do glifosato na rizosfera das plantas-alvo e não alvo. Inf Agron. 119: 3-5.

Silverman MP, Muñoz EP (1971) Fungal leaching of titanium form rock. Appl Microbiol. 22: 923-924.

Skocaj M, Filipic M, Petkovic J, Novak S (2011) Titanium dioxide in our everyday life; is it safe?. Radiol Oncol. 45 (4): 227-247.

Takala K, Olkkonen H (1985) Titanium content of lichens in Finland. Ann Bot Fenn. 22: 299-306.
Vaca CE, Wilhem J, Harms-Ringdahl M (1988) Interaction of lipid peroxidation products with DNA. A review. Mut Res. 195: 137-149.

Valpuesta V, Berteli F, Pérez-Prat E, Ccrrales E, Narasimham M, Botella MA, Bressan RA,

Pliego F, Hasegawa PM (1992) Cambios metabólicos y de expresión génica en plantas superiores en respuesta al estrés salino. Agriscientia. 9: 55-63.

Zhang J, Kirkham MB (1996) Lipid peroxidation in sorghum and sunflower seedlings as affected by ascorbic acid, benzoic acid, and propyl gallate. J Plant Physiol. 149: 489493. 